\title{
PENERAPAN MODEL PEMBELAJARAN PROBLEM BASED LEARNING DITINJAU DARI KEMAMPUAN KOMUNIKASI MATEMATIK
}

\author{
Lina Rihatul Hima \\ Universitas Nusantara PGRI Kediri \\ e-mail: lina.hima@yahoo.com
}

\begin{abstract}
This study aims to determine (1) how the implementation of learning mathematics using problem-based learning model of learning. In addition, to describe (2) how the students use the communication skills of mathematical learning model of problem-based learning. This study includes qualitative research, this kind of research using qualitative descriptive. The collection of data through observation, documentation, written test and interview. Data was taken two stages. The first stage is to give a written test instrument. The second stage is the interview of the subject selected. Making the research subjects were divided into three levels, namely a high skill level, ability level medium and low skill levels. Conclusion The results of this study were (1) reached learning the syntax or the suitability of the activities of teachers with lesson plans that have already been designed in using learning model of problem-based learning is progressing well with the percentage $84.97 \%$ or in the excellent category. While the activities of students during the learning progress with the learning model of problem-based learning has been performing well and is successful where the percentage reached $88.27 \%$ or in the excellent category.As for the students' mathematical communication skills in general in both criteria.
\end{abstract}

Keywords: Communication Mathematics, Problem Based Learning and learning

\begin{abstract}
Abstrak: Penelitian ini bertujuan untuk mengetahui (1) bagaimana pelaksanaan pembelajaran matematika dengan menggunakan model pembelajaran problem based learning. Selain itu juga untuk mendeskripsikan (2) bagaimana kemampuan komunikasi matematik siswa menggunakan model pembelajaran problem based learning.Penelitian ini termasuk penelitian kualitatif, jenis penelitian ini menggunakan kualitatif deskriptif. Pengumpulan data menggunakan observasi, dokumentasi, tes tertulis dan wawancara.Pengambilan data dilakukan dua tahap.Tahap pertama adalah memberikan instrumen tes tertulis.Tahap kedua adalah tes wawancara terhadap subyek terpilih. Pengambilan subjek penelitian dibagi dalam tiga tingkatan yaitu tingkat kemampuan tinggi, tingkat kemampuan sedang, dan tingkat kemampuan rendah.Kesimpulan hasil penelitian ini adalah (1) keterlaksanaan sintak pembelajaran atau kesesuaian aktivitas guru dengan RPP yang telah dirancang sebelumnya dalam menggunakan model pembelajaran problem based learning berlangsung dengan baik dengan prosentasenya $84,97 \%$ atau dalam kategori sangat baik. Sedangkan aktivitas siswa selama pembelajaran berlangsung dengan model pembelajaran problem based learning sudah terlaksana dengan baik dan bisa dikatakan berhasil dimana prosentasenya mencapai $88,27 \%$ atau dalam kategori sangat baik. Sedangkan untuk kemampuan komunikasi matematik siswa secara umum dalam kriteria baik.
\end{abstract}

Kata Kunci: Komunikasi Matematik, Problem Based Learning dan pembelajaran

\section{PENDAHULUAN}

Komunikasi matematik merupakan salah satu kemampuan yang harus dibekalkan kepada siswa dalam pendidikan di Indo- nesia seperti disebutkan dalam Peraturan Pemerintah Nomor 19 tahun 2005 tentang Standar Nasional Pendidikan (Depdiknas, 2006). Hal ini juga disampaikan oleh Rahardjito (2002: 11) bahwa proses belajar 
mengajar pada hakikatnya adalah proses komunikasi, yaitu proses penyampaian pesan dari sumber pesan melalui saluran/media tertentu ke penerima pesan. Hasil penelitian menunjukkan bahwa kemampuan komunikasi matematis siswa Indonesia masih kurang baik. Shadiq (2007) mendapati kenyataan bahwa di beberapa wilayah Indonesia yang berbeda, sebagian besar siswa mengalami kesulitan dalam menyelesaikan soal-soal pemecahan masalah dan menerjemahkan soal kehidupan sehari hari ke dalam model ma-tematika. Ini menunjukkan bahwa kemam-puan komunikasi dan pemecahan masalah matematika siswa masih kurang baik.

Demikian pula Izzati (2010) mendapatkan gambaran lemahnya kemampuan komunikasi siswa dikarenakan pembelajaran matematika selama ini masih kurang memberi perhatian terhadap pengembangan kemampuan ini. Hal yang sama juga ditemukan oleh Kadir (2010) bahwa kemampuan komunikasi matematis siswa SMP di pesisir masih rendah, baik ditinjau dari peringkat sekolah, maupun model pembelajaran. Mengingat akan pentingnya kompetensi komunikasi matematis bagi siswa, namun faktanya kompetensi ini belum memadai, maka perlu dilakukan penelitian yang mendalam tentang profil kemampuan komunikasi matematis siswa dalam menyelesaikan masalah matematika.

Berdasarkan hasil pengamatan dan wawancara penulis, diketahui bahwa kemampuan siswa dalam menyelesaikan soalsoal komunikasi masih rendah. Hal ini ditandai dengan siswa belum mampu untuk memberikan argumentasi yang benar dan jelas tentang soal-soal yang mereka jawab pada soal berbentuk cerita. Keberanian untuk menyampaikan ide-ide dan pendapat yang benar serta jelas masih kurang pada waktu proses pembelajaran. Untuk mengu- rangi terjadinya hal seperti ini, siswa perlu di-biasakan mengkomunikasikan secara lisan maupun tulisan idenya kepada orang lain sesuai dengan penafsirannya sendiri. Sehingga orang lain dapat menilai dan memberikan tanggapan atas penafsirannya itu. Melalui kegiatan seperti ini siswa akan mendapatkan pengertian yang lebih bermakna baginya tentang apa yang sedang siswa lakukan. Ini berarti guru perlu mendorong kemampuan siswa dalam berkomunikasi pada setiap pembelajaran. Pugalee (dalam NCTM, 2001: 297) mengatakan bahwa siswa perlu dibiasakan dalam pembelajaran untuk memberikan argumen atas setiap jawabannya serta memberikan tanggapan atas jawaban yang diberikan oleh orang lain, sehingga apa yang sedang dipelajari menjadi lebih bermakna baginya. Sehingga siswa dapat memahami konsep matematik dengan baik dan mampu mengembangkan kemampuan menyampaikan informasi atau mengkomunikasikan gagasan dari konsep matematika tersebut.

Menurut Greenes dan Schulman (1996: 159) komunikasi matematik adalah kemampuan (1) menyatakan ide matematika melalui ucapan, tulisan, demonstrasi, dan melukiskannya secara visual dalam tipe yang berbeda, (2) memahami, menafsirkan, dan menilai ide yang disajikan dalam tulisan, lisan, atau dalam bentuk visual, (3) mengkonstruk, menafsirkan dan menghubungkan bermacam-macam representasi ide dan hubungannya. Selanjutnya menurut Sullivan \& Mousley (Ansari, 2003: 17), komunikasi matematik bukan hanya sekedar menyatakan ide melalui tulisan tetapi lebih luas lagi yaitu kemampuan siswa dalam hal bercakap, menjelaskan, menggambarkan, mendengar, menanyakan, klarifikasi, bekerja sama (sharing), menulis, dan akhirnya melaporkan apa yang telah dipelajari. Jelas bahwa kemampuan 
komunikasi ma-tematik siswa perlu mendapat perhatian untuk lebih dikembangkan. Hal ini sesuai dengan harapan pemerintah seperti yang tercantum pada kurikulum bahwa dalam belajar matematika ada 4 kemampuan ma-tematik yang diharapkan dapat tercapai, kemampuan tersebut adalah kemampuan pemahaman konsep matematika, komunikasi matematik, penalaran matematik, dan koneksi matematik (Depdiknas, 2003: 3). Dengan memperhatikan kemampuan yang dituntut tersebut, jelaslah bahwa siswa dituntut memiliki kemampuan berpikir matematik. Kemampuan berpikir matematik tersebut memandang matematika sebagai proses aktif, dinamik, generatif, dan eksploratif.

Untuk dapat mengembangkan komunikasi matematik yang baik, guru dituntut dapat memilih model pembelajaran yang dapat memacu semangat setiap siswa untuk secara aktif ikut terlibat dalam pengalaman belajarnya. Salah satu alternatif model pembelajaran yang memungkinkan dikembangkannya keterampilan berpikir siswa (penalaran, komunikasi, dan koneksi) dalam memecahkan masalah adalah dengan me-nerapkan pembelajaran berbasis masalah (Problem based learning). Menurut materi implementasi kurikulum 2013 yang dike-luarkan oleh Depdiknas, (2013: 54) Pembelajaran berbasis masalah (Problem based Learning) merupakan sebuah model pembelajaran yang menyajikan masalah kontekstual sehingga merangsang siswa untuk belajar.

Dalam suatu kelas yang menerapkan pembelajaran berbasis masalah, siswa bekerja dalam tim untuk memecahkan masalah dunia nyata (real world). Dari permasalahan di atas mendasari penelitian ini dalam penggunaan model pembelajaran problem based learning untuk meningkatkan kemampuan komunikasi matematik siswa. Model pembelajaran ini diharapkan dapat menjadi solusi untuk mengatasi masalah rendahnya keaktifan siswa dalam mengkomunikasikan ide-ide matematisnya dan hasil belajarnya.

Berdasarkan uraian di atas, permasalahan secara umum pada penelitian ini adalah bagaimana penerapan model pembelajaran problem based learning ditinjau dari kemampuan komunikasi matematik. Sedangkan perumusan masalah secara khusus adalah bagaimana pelaksanaan pembelajaran matematika menggunakan model pembelajaran problem based learning dan bagaimana kemampuan komunikasi matematik siswa melalui penerapan model pembelajaran problem based learning ?

\section{METODE}

Jenis penelitian yang digunakan dalam penelitian ini adalah penelitian deskriptif. Metode deskriptif kualitatif adalah metode yang digunakan untuk meneliti pada kondisi objek yang alamiah (Sugiyono, 2006: 8). Tujuannya agar mendapat deskripsi yang utuh dan mendalam dari sebuah persoalan. Data dalam penelitian ini diperoleh melalui observasi, wawancara dan dokumentasi saat penelitian berlangsung dimana kehadiran peneliti sangat diperlukan dalam penelitian ini. Penelitian ini dilaksanakan di Kelas VIII Mts YPSM Baran Mojo Kediri tahun pelajaran 2014/2015.

Penentuan subjek ini menggunakan teknik purposive sampling, stratified sampling, random sampling (Fraenkel, 1932: 95). Subjek dalam penelitian ini adalah siswakelas VIII di MTs YPSM Baran Mojo. Proses analisis data pada penelitian ini meliputi tiga langkah, yaitu reduksi data (data reduction), penyajian data (data display), dan pengambilan kesimpulan/ verifikasi (Sugiyono, 2012: 247). 


\section{HASIL DAN PEMBAHASAN}

\section{Penentuan Subjek Penelitian}

Subjek penelitian di dapat dari hasil pos test dan observasi yang diberikan pada 33 siswa. Siswa yang terpilih sebagai subjek penelitian sebanyak 6 siswa, yang masingmasing terdiri dari dua siswa berkemampuan rendah, dua siswa berkemampuan sedang dan dua siswa berkemampuan tinggi. Keenam subjek tersebut diharapkan dapat mewakili seluruh tingkat kemampuan yang ada pada kelas VIII-1. Oleh karena itu, penentuan subjek penelitian didasarkan pada nilai soal penempatan dengan menggunakan metode penentuan kedudukan siswa berdasarkan standar deviasi pengelompokan atas tiga rangking yaitu tinggi, sedang dan rendah.

\section{Deskripsi Pengumpulan Data Penelitian}

Pengambilan data dalam penelitian ini dilakukan dua tahap. Tahap pertama adalah memberikan tes tertulisdan observasi saat pembelajaran berlangsung untuk mengetahui kemampuan komunikasi matematik siswa. Instrumen tersebut sebagai alat bantu pertama. Dilanjut tahap kedua adalah melaksanakan tes wawancara terhadap subjek terpilih. Wawancara dilaksanakan berdasarkan kesepakatan antara peneliti dengan subjek penelitian dengan tujuan agar kegiatan wawancara tidak mengganggu aktifitas pembelajaran subjek terwawancara. Seluruh rangkaian kegiatan pengambilan data penelitian dari ujian tes tertulis hingga wawancara, didokumentasikan dengan menggunakan kamera digital. Tujuan dokumentasi ini sendiri adalah untuk merekam seluruh kegiatan yang dilakukan dalam penelitian dengan baik, agar data yang dihasilkan dalam penelitian ini tidak diragukan.

\section{Deskripsi Data Hasil Penelitian Analisis Data Penelitian}

Analisis data dalam penelitian ini bertujuan untuk mendeskripsikan hasil belajar yang dialami oleh siswa dalam menyelesaikan soal pada materi Relasi dan Fungsi berdasarkan kemampuan komunikasi matematik siswa melalui pembelajaran problem based learning yang meliputi: Menyatakan peristiwa sehari-hari dalam bahasa atau simbol matematika, Menghubungkan benda nyata, gambar, dan diagram ke dalam ide matematika, menyatakan ideide matematis melalui lisan, tulisan, serta menggambarkan secara visual, menjelaskan idea, gagasan, konsep matematika dalam kehidupan sehari-hari ke dalam bahasa matematika dan menarik kesimpulan. Analisis data penelitian dilakukan terhadap enam siswa yang terpilih.Pemilihan ini dilakukan berdasarkan pertimbangan observasi dan tes hasil belajar yang dimiliki subjek terkait dengan kemampuan komunikasi yang dimiliki siswa.

\section{Analisis Pembelajaran dengan Penera- pan Metode Problem Based learning}

Data pelaksanaan pembelajaran diambil dari nilai observasi yang dilakukan terhadap guru dan siswa selama pembelajaran untuk melihat bagaimana keadaan pada saat pembelajaran matematika dengan menggunakan metode Problem Based learning yang dilakukan pada pertemuan pertama dan pertemuan kedua.

Pada observasi aktifitas guru fokus penilaiannya adalah kesusaian langkahlangkah pembelajaran di kelas dengan langkah-langkah pembelajaran yang ada pada RPP. Hasil rangkuman observasi aktivitas guru ketuntasan secara klasikal aktivitas guru dapat dikategorikan baik dan terbukti dari prosentase ketuntasan klasikal yang diperoleh mencapai $84,97 \%$. Sementara 
itu, hasil rangkuman observasi aktivitas siswa ketuntasan secara klasikal aktivitas siswa dapat dikategorikan sangat baik terbukti dari perolehan prosentase ketuntasan klasikal yang diperoleh mencapai $88,27 \%$.

\section{Analisis Data Kemampuan Komunikasi Matematik Siswa}

Data hasil tes kemampuan komunikasi matematik siswa diperoleh dari posttes yang telah dilaksanakan dengan materi relasi dan fungsi. Berikut ini data hasil tes kemampuan komunikasi matematik siswa. Dari hasil rangkuman komunikasi matematik pada pertemuan I dan pertemuan II rataratanya sebesar $70,22 \%$ artinya kemampuan siswa sudah dalam kategori baik. Ketuntasan secara klasikal komunikasi matematik siswa dapat dikategorikan baik, hal ini terbukti dari perolehan prosentase sebesar 71,25\%.

Untuk mengetahui kemampuan komunikasi matematis siswa tidak hanya berpacu pada hasil perolehan uji tes secara tertulis. Peneliti juga melakukan wawancara dengan subjek penelitian yang telah ditentukan untuk menjelaskan mengenai langkah-langkah penyelesaian soal yang telah diberikan. Hal tersebut akan menunjang peneliti untuk mendapatkan data yang valid dan mengetahui kemampuan komunikasi matematik siswa. Berikut deskripsi hasil tes dan hasil wawancara peneliti dengan setiap subjek pada penelitian kemampuan komunikasi matematik siswa pada materi relasi dan fungsi :

\section{Subjek ADP}

Berdasarkan hasil tes evaluasi diatas, dapat disimpulkan bahwa kemampuan komunikasi matematis subjek ADP mencapai kriteria "Sangat Baik" dengan perolehan total skor 14. Pada indikator 1 subjek ADP mendapatkan skor 4 yang menunjukkan bahwa subjek ADP dapat memberikan contoh suatu peristiwa seharihari yang berkaitan dengan relasi dengan benar dan tepat. Untuk indikator no 2 subjek ADP mendapatkan skor 4 yang menunjukkan bahwa subjek ADPdapat menghubungkan benda nyata, gambar, dan diagram ke dalam ide matematika, artinya ADP biasa menghubungkan relasi dan fungsi dengan tepat. Pada indikator 3 subjek ADP mendapatkan skor 3 juga yang menunjukkan bahwa subjek ADP dapat menyatakan ide-ide matematis yang berkaitan dengan relasi melalui lisan, tulisan, serta menggambarkan namun dalam menggambarkannya masih ada yang kurang tepat.

Pada indikator 4 subjek ADP mendapatkan skor 3 yang menunjukkan bahwa subjek ADP dapat menjelaskan idea, gagasan, konsep matematika dalam kehidupan sehari-hari ke dalam bahasa matematika dan mampu membuat kesimpulan dengan tepat dan benar pada setiap penyelesain soal. Pada saat peneliti melakukan wawancara dengan subjek ADP, Subjek ADP mampu menjawab pertanyaan dengan baik. Subjek ADP dapat menjelaskan bagaimana langkah-langkah untuk menyelesaikan ketiga soal yang diberikan tersebut.

\section{Subjek SNL}

Berdasarkan hasil tes evaluasi diatas, dapat disimpulkan bahwa kemampuan komunikasi matematik subjek SNLmencapai kriteria "Sangat Baik" dengan perolehan total skor 13. Pada indikator 1 subjek SNL mendapatkan skor 4 yang menunjukkan bahwa subjek SNL dapat memberikan contoh suatu peristiwa seharihari yang berkaitan dengan relasi dengan benar dan tepat. Untuk indikator no 2 subjek SNL mendapatkan skor 3 yang menunjukkan bahwa subjek SNL dapat menghubungkan benda nyata, gambar, dan diagram 
ke dalam ide matematika, artinya subjek SNL bisa menghubungkan relasi dan membedakan mana fungsi atau buka fungsi dengan tepat. Pada indikator 3 subjek SNL mendapatkan skor 3 yang menunjukkan bahwa subjek SNL dapat menyatakan ideide matematis yang berkaitan dengan relasi melalui lisan, tulisan, serta menggambarkan namun dalam menggambarkannya masih ada yang kurang tepat. Pada indikator 4 subjek SNL mendapatkan skor 3 yang menunjukkan bahwa subjek SNL dapat menjelaskan idea, gagasan, konsep matematika dalam kehidupan sehari-hari ke dalam bahasa matematika dan dalam membuat kesimpulan masih kurang tepat tetapi benar. Pada saat peneliti melakukan wawancara dengan subjek SNL, Subjek SNL mampu menjawab pertanyaan dengan baik. Subjek SNL dapat menjelaskan bagaimana langkah-langkah untuk menyelesaikan ketiga soal yang diberikan tersebut.

\section{Subjek IR}

Berdasarkan tabel diatas, dapat disimpulkan bahwa kemampuan komunikasi matematis subjek IR mencapai kriteria "Baik" dengan perolehan skor 11. Pada indikator pertama subjek IR mendapatkan skor 3 yang menunjukkan bahwa subjek IR dapat menyatakan peristiwa sehari-hari dalam bahasa atau simbol matematika, tetapi tulisannya masih kurang jelas atau kurang sistematis. Untuk indikator no 2 subjek IR mendapatkan skor 3 yang menunjukkan bahwa subjek IR dapat menghubungkan benda nyata, gambar, dan diagram ke dalam ide matematika dalam menyelesaikan masalah relasi dan fungsi dengan tepat dan benar. Pada indikator 3 subjek IR mendapatkan skor 2 yang menunjukkan bahwa subjek IR dapat menyatakan ide-ide matematis melalui lisan, tulisan, serta menggambarkannya secara visual, tetapi tulisan kurang jelas. Pada indikator 4 subjek IR mendapatkan skor 3 yang menunjukkan bahwa subjek IR dapat Menjelaskan idea, gagasan, konsep matematika dalam kehidupan sehari-hari ke dalam bahasa matematika namun kurang benar dan tidak sistematis dalam menarik kesimpulan. Pada saat peneliti melakukan wawancara, IR kurang mampu menjawab pertanyaan dengan baik. Subjek IR kurang dapat menjelaskan bagaimana langkah-langkah untuk menyelesaikan soal yang diberikan tersebut.

\section{Subjek MBU}

Berdasarkan tabel diatas, dapat disimpulkan bahwa kemampuan komunikasi matematik subjek MBU mencapai kriteria "Baik" dengan perolehan skor 10. Pada indikator pertama subjek MBU mendapatkan skor 2 yang menunjukkan bahwa subjek IR dapat menyatakan peristiwa sehari-hari dalam bahasa atau simbol matematika dengan benar dan sistematis. Untuk indikator no 2 subjek MBU mendapatkan skor 3 yang menunjukkan bahwa subjek MBU dapat menghubungkan benda nyata, gambar, dan diagram ke dalam ide matematika dalam menyelesaikan masalah relasi dan fungsi dengan benar namun kurang sistematis. Pada indikator 3 subjek MBU mendapatkan skor 3 yang menunjukkan bahwa subjek MBU kurang dapat menyatakan ide-ide matematis melalui lisan, tulisan, serta menggambarkannya namun masih kurang benar dan tidak sistematis. Pada indikator 4 subjek MBU mendapatkan skor 2 yang menunjukkan bahwa subjek MBU dapat menjelaskan ide, gagasan, konsep matematika dalam kehidupan sehari-hari ke dalam bahasa matematika namun kurang benar dan tidak sistematis dalam menarik kesimpulan. Pada saat peneliti melakukan wawancara dengan subjek MBU, dia kurang mampu menjawab 
pertanyaan dengan baik. Subjek MBU kurang dapat menjelaskan bagaimana langkahlangkah untuk menyelesaikan soal yang diberikan tersebut, dan harus "dipancing" terlebih dahulu dalam mengerjakannya.

\section{Subjek RW}

Berdasarkan tabel diatas, dapat disimpulkan bahwa kemampuan komunikasi matematik subjek RW mencapai kriteria "Kurang Baik" dengan perolehan skor 9. Pada indikator pertama subjek RW mendapatkan skor 3 yang menunjukkan bahwa subjek RW dapat menyatakan peristiwa sehari-hari dalam bahasa atau simbol matematika, tetapi tulisannya masih kurang jelas atau kurang sistematis. Untuk indikator no 2 subjek RW mendapatkan skor 2 yang menunjukkan bahwa subjek RW dapat menghubungkan benda nyata, gambar, dan diagram ke dalam ide matematika dalam menyelesaikan masalah relasi dan fungsi dengan baik, namun kurang benar dan tidak sistematis dalam penyelesaiaannya. Pada indikator 3 subjek RW mendapatkan skor 2 yang menunjukkan bahwa subjek RW dapat menyatakan ide-ide matematis melalui lisan, tulisan, serta menggambarkannya secara visual, tetapi masih kurang benar dan tidak sistematis. Pada indikator 4 subjek RW mendapatkan skor 2 yang menunjukkan bahwa subjek RW dapat menjelaskan ide, gagasan, konsep matematika dalam kehidupan sehari-hari ke dalam bahasa matematika namun kurang benar dan tidak sistematis dalam menarik kesimpulan. Pada saat peneliti melakukan wawancara dengan subjek RW, dia kurang mampu menjawab pertanyaan dengan baik.Subjek RW kurang dapat menjelaskan bagaimana langkah-langkah untuk menyelesaikan soal yang diberikan tersebut.

\section{Subjek PH}

Berdasarkan hasil tes yang diperoleh, dapat disimpulkan bahwa kemampuan komunikasi matematik subjek $\mathrm{PH}$ mencapai kriteria "Kurang Baik" dengan perolehan skor 8. Pada indikator pertama subjek PH hanya mendapatkan skor 2 yang menunjukkan bahwa subjek $\mathrm{PH}$ dapat menyatakan peristiwa sehari-hari dalam bahasa atau simbol matematika dengan baik namun masih kurang benar dan kurang sistematis. Untuk indikator no 2 subjek PH mendapatkan skor2 yang menunjukkan bahwa subjek $\mathrm{PH}$ dapat menghubungkan benda nyata, gambar, dan diagram ke dalam ide matematika dalam menyelesaikan masalah relasi dan fungsi namun masih kurang tepat. Pada indikator 3 subjek $\mathrm{PH}$ mendapatkan skor 2 yang menunjukkan bahwa subjek PH dapat menyatakan ide-ide matematis melalui lisan, tulisan, serta menggambarkannya secara visual, tetapi masih kurang benar dan tidak sistematis. Pada indikator 4 subjek PH mendapatkan skor 2 yang menunjukkan bahwa subjek PH dapat menjelaskan idea, gagasan, konsep matematika dalam kehidupan sehari-hari ke dalam bahasa matematika namun kurang benar dan tidak sistematis dalam menarik kesimpulan. Pada saat peneliti melakukan wawancara dengan subjek $\mathrm{PH}$, dia kurang mampu menjawab pertanyaan dengan baik. Subjek PH kurang dapat menjelaskan bagaimana langkah-langkah untuk menyelesaikan soal yang diberikan tersebut.

\section{Interpretasi dan Pembahasan}

Berdasarkan hasil data observasi, tes, dan wawancara yang telah dilakukan dengan keenam subjek penelitian, maka berikut ini akan dideskripsikan mengenai pembahasan hasil penelitian yang telah dilakukan dalam penerapan pembelajaran 
Problem Based Learning ditinjau dari kemampuan komunikasi matematika.

Penerapan Pembelajaran Problem Based Learning
Berdasarkan data hasil penelitian yang telah dilaksanakan, maka penerapan pembelajaran Problem Based Learning yang diperoleh dari hasil data observasi guru dan siswa diperoleh:

Tabel 1. Hasil RangkumanObservasi Aktivitas Guru

\begin{tabular}{lcccc}
\hline \multicolumn{5}{c}{ Prosentase Kegiatan Guru } \\
\hline \multicolumn{1}{c}{ Observasi } & Pendahuluan & K. Inti & Penutup & Klasikal \\
\hline Pert I & $75 \%$ & $87,5 \%$ & $81,25 \%$ & $81,25 \%$ \\
\hline Pert II & $87,5 \%$ & $91,07 \%$ & $87,5 \%$ & $88,69 \%$ \\
\hline Rata-rata & $81,25 \%$ & $89,28 \%$ & $84,37 \%$ & $84,97 \%$ \\
\hline Ket & Baik & Sangat Baik & Baik & Baik \\
\hline
\end{tabular}

Jadi hasil rangkuman observasi ak- bukti dari prosentase ketuntasan klasikal tivitas guru ketuntasan secara klasikal aktivi- $\quad$ yang diperoleh mencapai 84,97\%. tas guru dapat dikategorikan baik dan ter-

Tabel 2. Hasil Rangkuman Observasi Aktivitas Siswa

\begin{tabular}{lccc}
\hline & Skor & Prosentase $(\%)$ & Klasikal \\
\hline Pertemuan I & 319 & $83,04 \%$ & $84,37 \%$ \\
\hline Pertemuan II & 327 & $85,13 \%$ & $92.18 \%$ \\
\hline Rata-rata & 323 & $84,08 \%$ & $88,27 \%$ \\
\hline Keterangan & Baik & Sangat baik & Sangat baik \\
\hline
\end{tabular}

Berdasarkan hasil rangkuman observasi aktivitas siswa, ketuntasan secara klasikal aktivitas siswa dapat dikategorikan sangat baik terbukti dari perolehan prosentase ketuntasan klasikal yang diperoleh mencapai $88,27 \%$.

Tabel 3. Hasil kemampuan komunikasi matematika

\begin{tabular}{|c|c|c|c|}
\hline \multirow{2}{*}{$\begin{array}{c}\text { Subjek } \\
\text { Penelitian }\end{array}$} & \multicolumn{2}{|c|}{ Pengambilan Data } & \multirow{2}{*}{ Level } \\
\hline & Tes & Wawancara & \\
\hline ADP & Sangat Baik & Sangat Baik & Tinggi \\
\hline SNL & Baik & Sangat Baik & Tinggi \\
\hline IR & Cukup & Baik & Sedang \\
\hline MBU & Cukup & Baik & Sedang \\
\hline RW & Cukup & Baik & Sedang \\
\hline $\mathrm{PH}$ & Kurang Baik & Kurang Baik & Rendah \\
\hline
\end{tabular}

Berdasarkan tabel diatas, maka berikut ini akan disimpulkan mengenai kemampuan komunikasi matematika siswa yang ditinjau dari kemampuan menyelesaikan soal pada materi relasi dan fungsi. Pada kelompok atas, subjek ADP dan SNL berada pada level tinggi. Pada kelompok sedang, subjek IR berada pada level sedang sedangkan MBU, RW berada pada level sedang sedangkan subjek PH berada pada level rendah.
Keterkaitan antara pembelajaran problem based learning dengan kemampuan komunikasi matematika adalah bahwa dengan adanya pembelajaran tersebut kemampuan komunikasi matematik siswa semakin meningkat, dan hasil belajarnya juga semakin terlihat lebih baik. Berikut kesimpulan data hasil penerapan pembelajaran problem based learning ditinjau dari kemampuan komunikasi matematik siswa. 
Tabel 4. Penerapan Pembelajaran Problem Based Learning ditinjau dari Kemampuan Komunikasi Matematik Siswa

\begin{tabular}{|c|c|c|c|c|}
\hline \multirow{2}{*}{ Subjek } & \multicolumn{4}{|c|}{ Pengabilan Sumber Data } \\
\hline & Observ & Tes & Wawancara & Level \\
\hline ADP & Sangat baik & Sangat Baik & Sangat Baik & Tinggi \\
\hline SNL & Sangat baik & Baik & Sangat Baik & Tinggi \\
\hline IR & Sangat baik & Cukup & Baik & Sedang \\
\hline $\mathrm{MBU}$ & Baik & Cukup & Baik & Sedang \\
\hline RW & Cukup & Cukup & Baik & Sedang \\
\hline $\mathrm{PH}$ & Cukup & Kurang Baik & Kurang Baik & Rendah \\
\hline
\end{tabular}

Dari tabel diatas dapat diambil kesimpulan bahwa kemampuan komunikasi matematik siswa dalam menyelesaikan soal relasi dan fungsi setelah diterapkan metode problem based learning yaitu kemampuan komunikasi matematik siswa yang tergolong dalam kemampuan tingg subjek ADP dan SNL, kemampuan sedang adalah subjek MBU, IR dan RW dalam menyelesaiakan soal relasi dan fungsi termasuk kriteria baik dan kemampuan komunikasi metematik siswa yang tergolong dalam kemampuan rendah adalahsubjek $\mathrm{PH}$, subjek tersebut termasuk kedalam kemampuan rendah dalam menyelesaikan soal relasi dan fungsi. Secara umum komunikasi matematik siswa dari keenam subjek diatas termasuk dalam kriteria baik.

\section{SIMPULAN}

Berdasarkan hasil penelitian dan pembahasan terhadap hasil analisis data penelitian, yang terkait dengan penelitian menggunakan model pembelajaran problem based learning yang ditinjau dari kemampuan komunikasi matematik siswa di kelas VIII di Mts YPSM Baran Maesan Mojo Kediri yang maka dapat diambil kesimpulan sebagai berikut: (1) Keterlaksanaan sintak pembelajaran atau kesesuaian aktivitas guru dengan RPP yang telah dirancang sebelumnya dalam menggunakan model pembelajaran problem based learning berlangsung dengan baik. Adapun hasil analisis data yang dilakukan adalah aktivitas guru pada pertemuan I mencapai $81,25 \%$ dan pada pertemuan I mencapai $88,69 \%$. Dengan demikian indikator aktivitas guru sesuai sintak pembelajaran memenuhi kriteria baik. (2) Aktivitas siswa selama pembelajaran berlangsung dengan model pembelajaran problem based learning sudah terlaksana dengan baik dan bisa dikatakan berhasil, hal ini dibuktikan dari hasil analisis data adalah aktivitas siswa pada pertemuan I mencapai $83,04 \%$ dan pada pertemuan II mencapai $85,13 \%$. Secara klasikal aktivitas siswa selama proses pembelajaran mencapai $88,27 \%$ atau dalam kategori sangat baik. Sedangkan kemampuan komunikasi matematik siswa yang tergolong dalam kemampuan tinggi subjek ADP dan SNL, kemampuan sedang adalah subjek MBU, IR dan RW dalam menyelesaikan soal relasi dan fungsi termasuk kriteria baik, kemampuan komunikasi matematik siswa yang tergolong dalam kemampuan rendah adalahsubjek PH, subjek tersebut termasuk kedalam kemampuan rendah dalam menyelesaikan soal relasi dan fungsi. Komunikasi matematik siswa secara umum dari keenam subjek diatas termasuk dalam kriteria baik.

\section{DAFTAR PUSTAKA}


Agustyaningrum, Nina. 2011. Implementasi Model Pembelajaran Learning Cyle 5E untuk Meningkatkan Kemampuan Komunikasi Matematis Siswa kelas IX B SMP Negeri 2 Sleman. Seminar nasional matematika dan pendidikan matematika yogyakarta, 3 desember 2011///Diunduh pada tanggal 24 Desember 2014 pukul 12: $59 \mathrm{PM}$

Arifin. 2014. Penelitian Pendidikan. Bandung: Rosda

Arikunto. 2002. Dasar-dasar Evaluasi Pendidikan. Jakarta: Bumi Aksara

Arikunto. 2012. Dasar-dasar Evaluasi Pendidikan. Jakarta: Bumi Aksara

Bansu Irianto Ansari. (2003). Menumbuh Kembangkan Kemampuan Pemahaman dan Komunikasi Matematika Siswa SMU melalui Strategi ThinkTalk-Write. Disertasi doktor, tidak diterbitkan, Universitas Pendidikan Indonesia, Bandung.

Darkasyi, Muhamad,dkk. 2014.Peningkatan Kemampuan Komunikasi Matematis dan Motivasi Siswa dengan Pembelajaran Pendekatan Quantum Lear-ning pada Siswa SMP Negeri 5 Lhokseumawe. Jurnal didaktik matematik Vol 1, No. 1 April 2014 /// diunduh tanggal 14 Desember 2014 pukul 12 : 03 PM

Departemen Pendidikan Nasional. (2003). Kompetensi Dasar Mata Pelajaran Matematika Sekolah Menengah Atas dan Madrasah Aliyah. Jakarta: Depdiknas.

Departemen Pendidikan Nasional. (2005). konsep peraturan pemerintah nomor 19 tahun 2005 tentang standar nasional pendidikan. Jakarta: Depdiknas

Depdiknas. 2013. Materi Pelatihan Kurikulum 2013. Jakarta: Kemendikbud
Fahrurrozi. 2011. Penerapan pembelajaran berbasis masalah untuk meningkatkan kemampuan berpikir kritisdan komunikasi matematis siswa sekolah dasar. Edisi Khusus No. 1, Agustus 2011/// Diunduh pada tanggal 15 januari 2015 pukul 9: $46 \mathrm{PM}$

Heruman. 2013. Model Pembelajaran Matematika Di Sekolah Dasar. Bandung: Remaja Rosda Karya

Moleong. 2014. Metodelogi Penelitian Kualitatif. Bandung: Remaja Rosdakarya

Pribadi, Benny. 2009. Model Desain Sistem Pembelajaran. Jakarta: Dian Rakyat

Pugalee, D.A. (2001). Using Communication to Develop Students' Mathematical Literacy. Journal Research of Mathematics Education, 6, 296299. Diambil pada tanggal 15 januari 2015, diunduh pukul 7: 44 pm dari http://www.my.nctm.org/ercsources/article-summary.asp?URI= MTMS2001-01-296a\&from=B.

Rusman. 2013. Model-Model Pembelajaran mengembangkan Profesionalisme Guru Edisi 2- 6. Jakarta: Rajawali Perss

Russefendi. 1980. Pengajaran Matematika Modern. Bandung: Tarsito

Sudrajat.(2001). Penerapan SQ3R pada Pembelajaran Tindak lanjut untuk Peningkatan Kemampuan Котиnikasi dalam Matematika Siswa SMU.Tesis Magister, tidak diterbitkan, Universitas Pendidikan Indonesi, Bandung.

Sugiono. 2010. Belajar dan pembelajaran. Kediri: UNP

Sugiyono. 2014. Memahami Penelitian Kualitatif. Bandung: Alfabeta

Suherman, Tatang. 2007. Pembelajaran Berbasis Masalah untuk Meningkatkan Kemampuan Berpikir Mathematis Tingkat Tinggi Siswa Sekolah 
Menengah Pertama.Journal Research of Mathematics Education, No.I Vol. I Januari 2007 diunduh 24 Desember 2014 pukul 1: 06 pm

Suprihatiningrum, Jamil. 2013. Strategi Pembelajaran, Teori dan Aplikasi. Jogjakarta: Ar-Ruzz Media

Suyadi. 2013. Strategi Pembelajaran Pendidikan Berkarakter. Bandung: Remaja Roesdakarya

Tandiling, Eddy. 2011. The Enhancement of Mathematical Communication and Self Regulated Learning of Senior
High School Students Through PQ4R Strategy Accompanied by Refutation Text Reading disajikan dalam International Seminar and the Fourth National Conference on Mathematics Education 2011 Department of Mathematics Education, Yogyakarta State University. Yogyakarta, July 21-23 2011 /// Diunduh pada tanggal 15 januari 2015 pukul 8: $37 \mathrm{PM}$

Trianto. 2007. Model Pembelajaran Inovatif. Jakarta: Prestasi Pustaka 